\title{
A revision of ligule and labium in Isoëtes
}

\author{
H. K. GOSWAMI \\ Department of Botany, Government Science College, Gwalior, INDIA
}

(Received: August 22, 1975)

\begin{abstract}
The developmental aspects of ligule, labium and sporangium are studied and differences in structure and function are mentioned. This paper also revises the conventional position of ligule and labium in Isoëtes.
\end{abstract}

\section{INTRODUCTION}

The ligule is a tongue shaped, delicate-parenchymatous flap seated in a cavity just above the adaxial sporangium of lepidodendrids, sigillarians, and in modern flora, in Selaginella, Isoëtes and Stylites. It originated in Devonian and is indispensibly associated with giant lycopods of Carboniferous. Two series, eligulatae and ligulatae are since then maintained and it is surprising, that while there has been tremendous amount of evolution in ligulatae, from the arborescent habit to small root bearing axes of Isoëtes, there has been insignificant change in eligulatae; Lycopodium is almost similar to its ancestor Baragwanthia.

Ligule is of variable shapes and sizes. In Lepidodendron and Lepidophlois it is preserved as a small triangular print, in Lepidostrobus (M a sle n, 1898) it is seen as a small pointed body about half a $\mathrm{mm}$ in height (S c o t t, 1923). In the herbaceous carboniferous genus Miadesmia, the ligule is an elaborate and well developed structure.

Among living genera, Isoëtes presents numerous shapes; in I. lacustris Mohl in 1845 described it to be ovate, lanceolate or cordate at the base, and elongate, acuminate towards the apex. In a specimen of small size, the length was about $3 \mathrm{~mm}$ but in the large plant the ligule measured $15 \mathrm{~mm}$ in length and $6 \mathrm{~mm}$ in breadth. W e s t and $\mathrm{T}$ a k e d a (1915) figured lobes of ligule at the broad base in I. japonica, while margins were lacerate. Such variability is also demonstrable in the genus Selaginella. 
H a r ve y-G i b s on (1896) considered Selaginella ligule as a specialized ramentum commonly found in pteridophytes. F a r mer (1890) even considered the ontogeny of Selaginella and Isoëtes ligules to be different from each other, although, its being seated in tracheidal cup of glossopodium and general plan seemed identical. Ligule in Stylites is not fully described although we expect similar morphogenesis.

In none of these genera fossil as well as living, a special structure, the labium has never been known which was first described by $\mathrm{Br}$ a un (1863) in Isoëtes. Strangely enough, not only the significance but even the presence of labium has been ignored by pteridologists who have either worked or compiled (B ower, 1935; Eam es, 1936; W e s t and Takeda, 1915; Foster and Gifford, 1959; Sporne, 1970; Bierhorst, 1971) after the classical paper by Scott and Hill (1900). Being unaware of the papers by Braun and Scott and Hill. Pilot (1959) and H a 11 (1971) designated labium as "pseudoligule".

It is the purpose of this paper therefore, to stress the position of ignored saddle and labium and bring forth many hitherto uncared facts about the development of sporangium, ligule and velum in Isoëtes.

\section{MATERIALS AND METHOD}

More than a thousand sporangia belonging to four species of Isoëtes viz: I. pantii Goswami and Arya, I. coromandelina L., I. sampathkumarinii Rao and I. panchananii Pant and Srivastava have been examined over five years. Young and mature sporangia were processed for microtomy and sections were cut in transverse and longitudinal planes at $8-12 \mu$.

Sections were double stained in aqueous safranin - crystal violet and safrannin - fast green and mounted in Canada balsam. Photographs and camera lucida sketches were immediately obtained and the magnifications are shown in the legend.

\section{OBSERVATION}

A streak of cells is laid out on the lower part of the ventral face of young sporophyll, this in $I$. pantii is placed at the lower 6/7th part (av. of 50). Cells divide here very fast and the entire structure appears balloon shaped (Figs. 1 \& 2), being called as "ligular zone". A group of sporangial initials below this zone, develop a young sporangium (Fig. 3). Differentiation in ligular zone forms a linear streak of cells which B r a u n (1863) called Saddle (Sella); this demarcates the linear pit in between sporophyll and itself, a plateform for ligule to emerge. The ligular tissue originates 

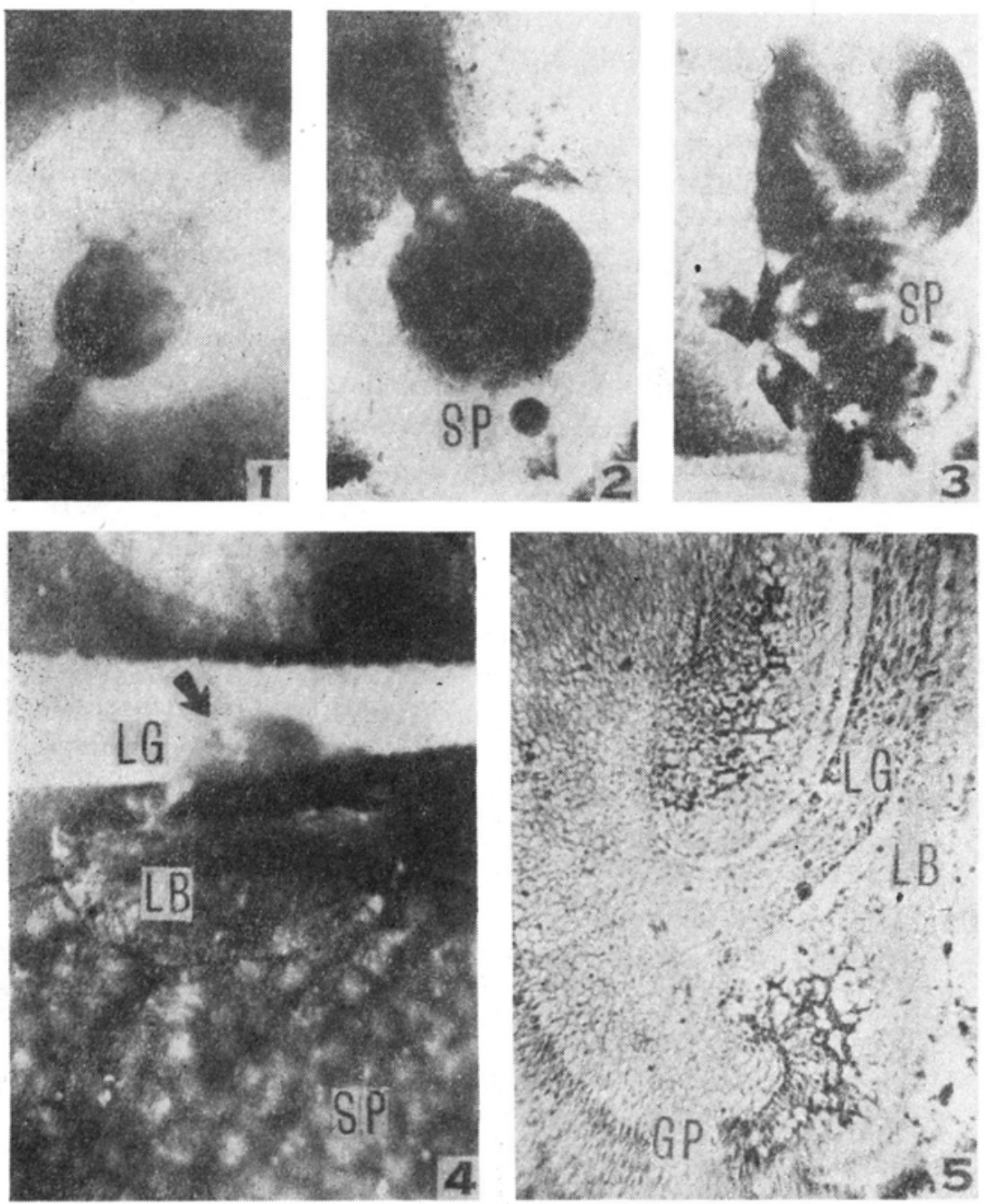

Figs. 1-5. I. pantii, Fig. 1. Young sporophyll showing horse shoe shaped ligular zone (X 10); Fig. 2., Development of sporongial zone below the baloon of ligular zone ( $\times 10)$; Fig. 3., Development and enlargement of sporangial tissue; Fig. 4., A portion of sporophyll showing spongy shrinked ligule (white strip of paper placed below), note the downwardly folded labium above the sporangium; Fig. 5., Longitudinal section showing massive bean shaped glossopodium and ligule, note the development of transfusion tissue at the base of glossopodium in the tissue of labium $(\times 50)$

Abbreviations used in Figures $1-15$

LB - labium, LG - ligule, GP - glossopodium, SP - sporangium, SD - saddle, TR trabeculae, TF - transfusion tissue, HT - haustorial tissue

in the space thus created in between sporophyll and saddle. Simultaneously, saddle gives rise to the upward growing structure, the labium.

Labium in I. pantii is broader than long (Fig. 4); ligule is soft, delicate, slimmy and tongue shaped being over-arched by tough "cartilagineous" 


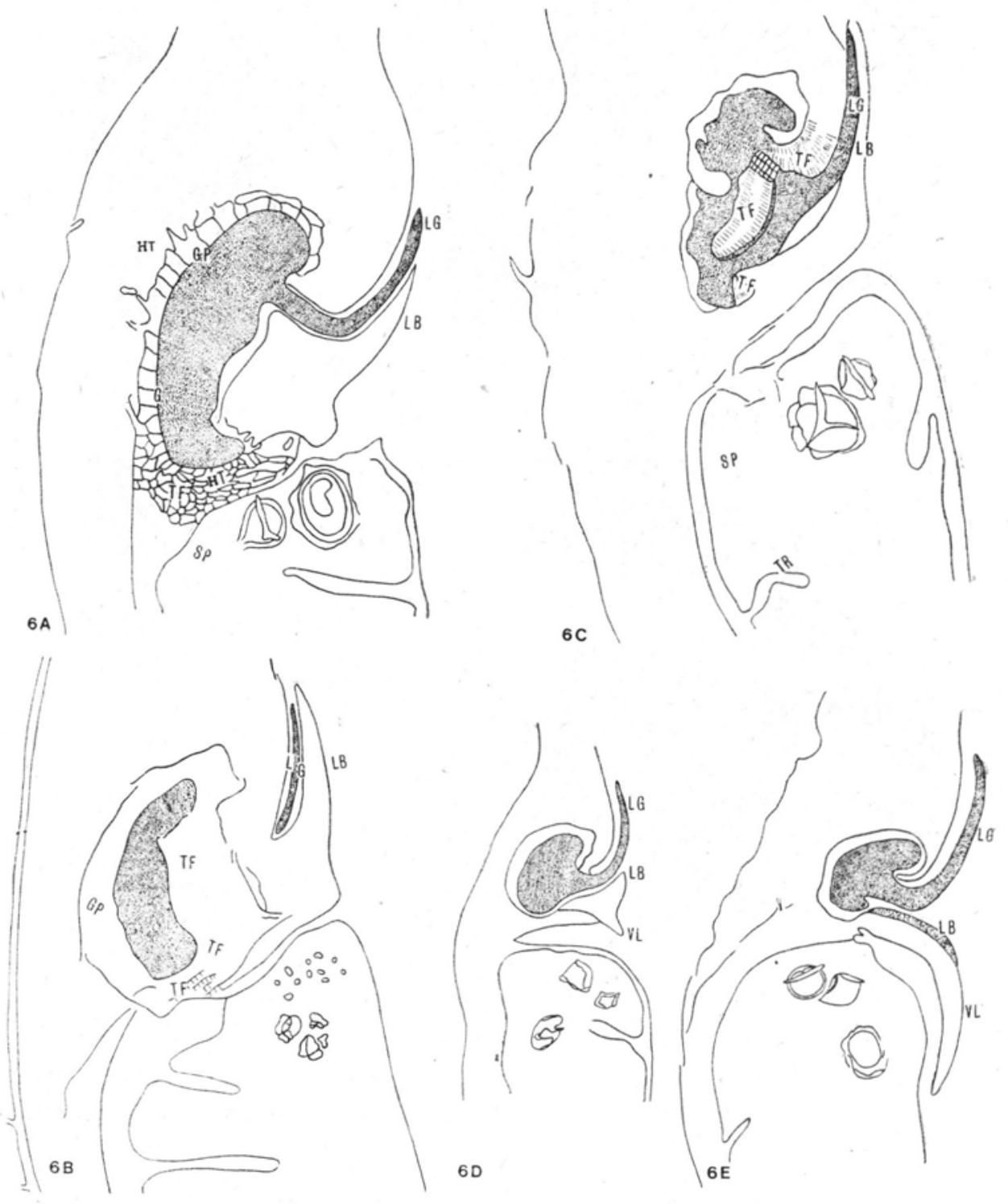

Figs. 6A-E, I. pantii, A. - L. S. of megasporophyll showing ligule (LG), labium (LB) and development of "haustorial" tissue around glossopodium. Note the development of thick walled irregular cells reaching the sporangium; B. - Separation of ligule from its base glossopodium (GP) due to the development of transfusion tissue (TF), see also Fig. 7; C. - final separation of ligule from glossopodium, note the development of new tracheary elements (TF) in the area (see also Fig. 8); I. Sampathkumarinii, D. - L. S. of a megasporangium shows ligule, ill developed labium and developing velum (see also Fig. 11);E. - L. S. throught a mature sporangium showing downwardly growing velum (VL) upward ligule and in between is the shrivelled strip of labium adherent on the velum (see also Fig. 12). 
flap, the labium. Insertion of ligule by the glossopodium (Fig. 5) becomes: evident only in longitudinal sections.

Brick cells of both ligule and labium are thin walled; ligule cells are filled with dense contents of proteophillic nature. The glossopodium is surrounded by a sheath of isodiametric cells, the central portion of the radial walls appear to be lignified (Figs. 6A). Certain cells of the leaf base outside the glosopodium become converted into short reticulate tracheids ( $\mathrm{S} \mathrm{m} \mathrm{i} \mathrm{th,} \mathrm{1900;} \mathrm{W} \mathrm{e} \mathrm{s} \mathrm{t} \mathrm{and} \mathrm{T}$ a k ed a, 1915; see Figs. 5 \& 6B).

Thus series of longitudinal sections of numerous micro- and megasporangia reveal following interesting features:

(I) The glossopodium becomes massive and few tracheids develop towards the sporangium (Fig. 5).

(II) Tracheids increase in size and number and simultaneously the peripheral cells of glossopodium become elongated and compressed looking haustorial in function (Fig. 6A).

(III) Gradually, ligule shrivels down (not described before) and in $I$. pantii, irrespective of type of sporangium, it ultimately is chopped off from the base (Figs. 6C, 7, 8).

This is resulted due to the development of intruding parenchymatous and new transfusion tissue from three sides to replace the: ligular tissue (Figs. 6B \& 7).

(IV) A mature sporangium then shows only a few celled, thick, long and detached strip of cells in the channel between the sporophyll and labium.

The bean shaped glossopodium becomes completely isolated structure as if it had no relation with the ligule (Figs. 6C, 8 \& 9); it is now surrounded by newly formed transfusion tissue.

(V) Tracheidal tissue develops near the base of the labium indicating a new area of water supply (Fig. 10). While the upper layer of the saddle forms ascending labium the lower tissue, in certain species, forms velum developing in the downward direction to keep pace with the developing sporangium (Fig. 6D \& 11).

In species with velum, eg. I. sampathkumarinii and I. panchananii, it is the labium not ligule which is eliminated at maturity. Medium sized sporangia show the shrunken labium lying below the ligule indicating its checked growth due to the development of velum. Therefore, labium which remains a major unaffected structure in velumless species, here, becomes rudimentary and may be seen adhering on the upper portion of the velum (Figs. 6E \& 12). Subsequently, labium disappears and the longitudinal section through such a sporangium, especially at the margins, shows the conventional figure of ascending ligule and decending velum.

The tendency of detachment of ligular flap with its massive glossopodium is also demonstrable in species with velum. Sagittal lon- 
gitudinal sections through the sporangium of $I$. panchananii (Figs. 13-15) exhibit numerous stages and finally, in a sporangium with mature spores, the ligular flap lies freely in the ligular cavity. Obviously, open ligular cavity denotes the one time attachment of ligular flap on its margins. This discourse should also account for fossils and various stages known may be the states of development at the time of preservation.

Such developmental changes in saddle, ligule, labium and velum, going hand in hand with the maturing sporangium have been described for the first time; otherwise, present observations regarding general ontogeny and structures are strictly pertinent to $\mathrm{Scott}$ and Hill (1900).

\section{DISCUSSION}

There is a widespread belief (Foster and Gifford, 1959; Spor$\mathrm{n}$ e, 1970; B i e r hors t, 1971) that ligule is either a secretory or nutritive organ or both, which by exuding water and mucilage, serves to keep young leaves and sporangia in a moist condition. The frequent development of tracheids between the ligule sheath and vein of the microphyll indicate direct conduction of water to the base of ligule. In I. pantii, tracheidal tissue develops from the base of the ligule towards the sporangial wall or near trabeculae.

S mith (1900) and West and Takeda (1915) also found the foot region of the ligule becoming very massive and its lateral portions grew upwardly and downwardly as pairs of horn like processes. F o s t e r and $\mathrm{G}$ if f o r d (1959) referred to similar situations in other species; in I. pantii basal cells of glossopodium appear like "haustorial in function". These cells remind of palisade structures in the foot region of Anthoceros sporophyte.

With the recognition of labium as a definite structure, it can be argued the ligule, in its greater span, exudes water but at its brink, becomes haustorial in function.

Ligule must have evolved with some common cause, for it is present in arborescent (lepidodendrids) as well as herbaceous lycopods (Miadesmia) but at the same time, absent in ancient Baragwanthia and modern Lycopodium. Geologically, the elevation of the Caledonian chain (S ew a $\mathrm{r} d, 1933$ ) have been a dominating factor in bringing about the invasion and subsequent colonization of the land during late Silurian and Early Devonian. This must have had a far reaching influence on the flora and lycopods colonizing different areas of land would have experienced water scarcity. Ligule, with every probability, must have had a far reaching influence on the flora and lycopods colonizing different areas of land would have experienced water scarcity. Ligule, with every probability, must have originated during this time. 

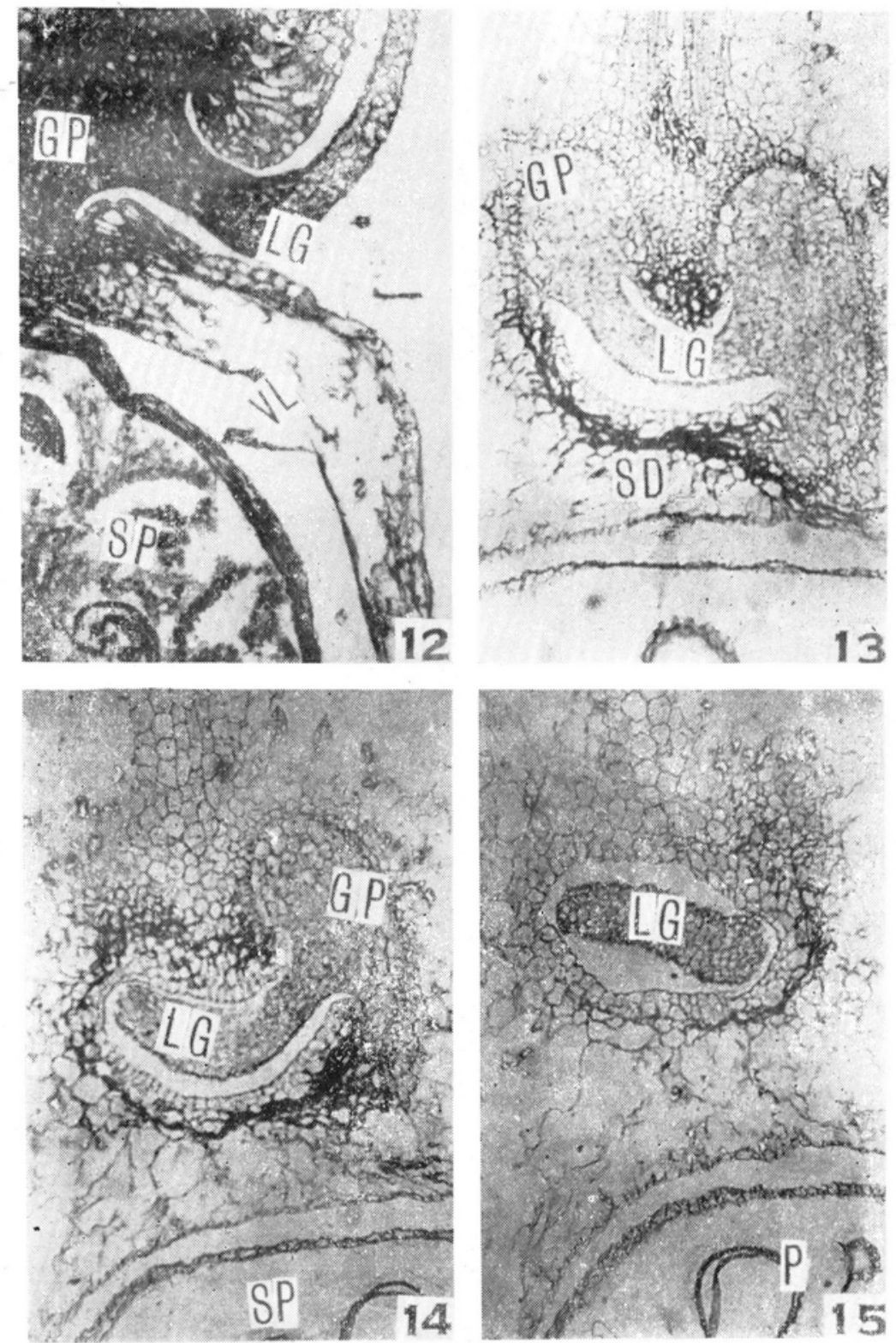

Fig. 12. L. S. passing through the middle of a mature sporangum showing ligule, velum covering sporangium and shrivelled strip of labium lying below the ligule $(\times 50)$; Fig. 13. I. panchananii. all figs. $\times 50$. Longitudinal sagittal sections of the megasporophyll showing bulbous ends of glossopodium and solt parenchymatous ligular flap in the cavity. Note the thick ridge of tissue, the saddle form:ng velum; Fig. 14. detached ligular flap from its left base of glosscpodium due to the treacheary elements (upper dark cells). Note the tissue of velum developing from saddle (SD.), Fig. 15. Completely detached ligular flap lying in the cavity 
But in none of the fossil as well as living lycopod except Isoëtes, labium has been never known or reported. In Selaginella the ligule develops under the immediate shelter of the overeaching sporophyll. Due to the greater demand of abnormally big and comparatively, exposed sporangia of Isoëtes saddle develops labium as an adjuvant structure to ligule. Therefore, labium is a structure "On demand"; Its selective advantage lies in the fact that at maturity, outer most sporophylls spread out (to some extent) the labium offers, with its tough texture, a genuine shelter to the ligule. In the genetically divergent species where velum develops, the labium does not assume its usual shape and size and shrivels at an early age.

Acknowledgements

I am grateful to Professor D. D. P a n t for facilities and suggestions, to $\mathrm{Mr}$. B. S. A r y a-N arsingh gar h and Prof. M. S. A garkar-Rewa, for their help with collections of Isoëtes plants. The travel grant to Allahabad by the Jiwaji University Gwalior is also gratefully acknowledged.

\section{REFERENCES}

B i e r horst D. W., 1971. Morphology of Vascular plants. Collier - Mac Millan Ltd. London.

B o w e r F. O., 1935. Primitive Land plants Mac Millan, London.

* B r a u n A., 1863. Ueber die Isoëtes Arten der Insel Sardinien. Monatsberichten K. Preuss. Akad. der Wiss. Zu Berlin; aus dem Jahre.

E a mes A. J., 1936. Morphology of Vascular plants. Lower groups. McGraw-Hill, New York.

F a r m e r J. B., 1890. On Isoëtes lacustris Ann, Bot. 5: 37-62.

Foster A. S. and E. M. Gifford. 1959. Comparative Morphology of Vascular Plants. W. H. Freeman, California.

H a 11 J. B. Observations on Isoëtes in Ghana. Bot. J. Linn. Soc. 64: 117-139.

H a r ve y-Gibs on R. J., 1896. Contributions towards a konwledge of the anatomy

of the genus Selaginella II. The ligule Ann. Bot. 10: 77-88.

M a s 1 e n A. J., 1898. The ligule in Lepidostrobus. Ann Bot. 12.

* P i t o t A., 1959. Contributions à l'étude des Isoëtes africans: Isoëtes melanotheca

Alston. Bull. Inst. fr. Afr. noire (Ser. A), 21: 900-920.

S eward A. C., 1933. Plant life through the ages. Reprint (1966) by Hafner Publ. Co. New York.

S c ot t D. H., 1923. Pteridophyta Reprinted in 1962 by Hafner Publ. New York.

S cott D. H. and T. G. Hill, 1900. The structure of Isoëtes hystrix Ann Bot., 14: $413-454$.

S mith R. W., 1900. The structure and development of the sporophylls and sporangia of Isoëtes, Bot. Gaz. 29: 225-258; 323-346. 
S porne K. R., 1970. The morphology of pteridophytes, London.

West C. and H. T a ke da, 1915. - X. On Isoëtes japonica. Trans. Linnean Soc. London 8: 333-376.

\author{
Author's address \\ H. K. Goswami Ph. F. L. S. \\ $83-\mathrm{G}$ - Jawahar Colony \\ Gwalior (M. P.); India
}

Rozwój, struktura i funkcje ligula $i$ labium u różnych przedstawicieli. rodzaju Isoëtes

Streszczenie

Opisano rozwój ligula, labium i sporangium w rodzaju Isoëtes, oraz podkreślono różnice w ich funkcjach i strukturze.

Omówiono również poglądy wielu autorów na rolę i ewolucję tych organów. 